1982

\title{
The Constitutional Guarantee of Aboriginal and Treaty Rights
}

\author{
Brian Slattery \\ Osgoode Hall Law School of York University, bslattery@osgoode.yorku.ca
}

\section{Source Publication:}

Queen's Law Journal. Volume 8, Numbers 1 \& 2 (1982-1983), p. 232-273.

Follow this and additional works at: https://digitalcommons.osgoode.yorku.ca/scholarly_works

Part of the Constitutional Law Commons, Indian and Aboriginal Law Commons, Property Law and Real Estate Commons, and the Public Law and Legal Theory Commons

\section{Recommended Citation}

Slattery, Brian. "The Constitutional Guarantee of Aboriginal and Treaty Rights." Queen's Law Journal 8.1/2 (1982-1983): 232-273.

This Article is brought to you for free and open access by the Faculty Scholarship at Osgoode Digital Commons. It has been accepted for inclusion in Articles \& Book Chapters by an authorized administrator of Osgoode Digital Commons. 
The Constitutional Guarantee of Aboriginal and Treaty Rights

\section{BRIAN SLATTERY*}

A critic of the new Constitution could be forgiven for saying that the sections regarding aboriginal rights lead us from darkness to darkness, that they substitute impenetrable obscurity for what was formerly mere shadowy gloom. In fact, the provisions have a certain oracular quality, hinting in a few enigmatic phrases at hidden strata of meaning. They pose an unusually difficult task for a court, required, on the basis of only the most general of indications, to resolve disputes of daunting historical and theoretical dimensions.

My aim here is to attempt to make sense of these provisions and to suggest a workable framework for their application. The attempt is tentative and necessarily somewhat speculative. The conclusions that I draw are by no means the only ones possible. But they have the advantage of comparative simplicity, and, if nothing else, may serve to stimulate thought on some rather fundamental issues. ${ }^{1}$

* Faculty of Law, Osgoode Hall Law School, York University. I would like to thank Professor Peter Hogg for his comments on an earlier version of this paper, and Mr. Keith Boswell for invaluable research assistance.

1 For other discussions of the aboriginal rights provisions see: MeNeil, "The Constitutional Rights of the Aboriginal Peoples of Canada" (1982), 4 Supreme Court Law Review 255; Lysyk, "The Rights and Freedoms of the Aboriginal Peoples of Canada," in Tarnopolsky and Beaudoin, eds., The Canadian Charter of Rights and Freedoms (1982), 467; Hogg, Canada Act 1982 Annotated (1982), 69, 81-83, 84-85. A useful discussion of an earlier version of these provisions is found in Sanders, "Aboriginal Peoples and the Constitution" (1981), 19 Alberta Law Review 410. For general background, see: Cumming and Mickenberg, eds., Native Rights in Canada, 2nd ed. (1972); Lysyk, "The Unique Constitutional Position of the Canadian Indian" (1967), 45 Canadian Bar Review 513; Lysyk, "Constitutional Developments relating to Indians and Indian Lands: An Overview," in Special Lectures of the Law Society of Upper Canada, The Constitution and the Future of Canada (1978), 201; Lysyk, "The Indian Title Question in Canada: An Appraisal in the Light of Calder" (1973), 51 Canadian Bar Review 450; Slattery, The Land Rights of Indigenous Canadian Peoples (D. Phil. Thesis, Oxford University, 1979; reprinted by the University of Saskatchewan Native Law Centre, 1979); Slattery, Ancestral Lands, Alien Laus: Judicial Perspectives on Aboriginal Title (University of Saskatchewan Native Law Centre, 1983). 
The enterprise is complicated by the fact that the relevant sections are, at the moment, in transition. On 16 March 1983, the First Ministers' Conference on Aboriginal Constitutional Matters agreed to make amendments to the existing sections concerning aboriginal rights. ${ }^{2}$ Resolutions to this effect will be laid before the respective legislatures before the end of the year. It seems likely that the process will be successful. So I will consider here the proposed new provisions along with the old, and discuss the effect of each separately. First, a brief review of the relevant sections.

\section{1) THE MAIN PROVISIONS}

Section 35 of the Constitution Act, 1982 (henceforth "the Constitution") now states as follows:

(1) The existing aboriginal and treaty rights of the aboriginal peopies of Canada are hereby recognized and affirmed.

(2) In this Act, "aboriginal peoples of Canada" includes the Indian, Inuit and Métis peoples of Canada.
(1) Les droits existants - ancestraux ou issus de traités - des peuples autochtones du Carada sont reconnus et confirmés.

(2) Dans la présente loi, "peuples autochtones du Canada" s'entend notamment des Indiens, des Inuit et des Métis du Canada.

Under the March 16th agreement, two further subsections will be added:

(3) For greater certainty, in subsection (1) "treaty rights" includes rights that now exist by way of land claims agreements or may be so acquired.

(4) Notwithstanding any other provision of this Act, the aboriginal and treaty rights referred to in subsection (1) are guaranteed equally to male and female persons.
(3) Il est entendu que sont compris parmi les droits issus de traités, dont il est fait mention au paragraphe (1), les droits existants issus d'accords de revendications territoriales ou ceux susceptibles d'être ainsi acquis.

(4) Indépendamment de toute autre disposition de la présente loi, les droits - ancestraux ou issus de traitês - visés au paragraphe (1) sont garantis également aux personnes des deux sexes.

The recent agreement also proposes to add a new section 35.1, which states that any future amendments to the major constitutional provisions regarding aboriginal peoples will first be

- 21983 Constitutional Accord on Aboriginal Rights, First Ministers' Conference on Aboriginal Constitutional Matters; Document 800 - 17/041, revised; Ottawa, March 15-16, 1983. The accord was signed by the federal government, nine provincial governments, and the representatives of six native organizations. The government of Quebec did not sign. 
discussed at a Conference of First Ministers to which aboriginal representatives will be invited.

These sections make up Part II of the Constitution, entitled "Rights of the Aboriginal Peoples of Canada." They fall outside the Canadian Charter of Rights and Freedoms, found in Part I of the Act. Their location has several significant consequences. Section 35 is not qualified by section 1 of the Charter, which allows for "reasonable limits" to be imposed by law on Charter rights, so long as they can be demonstrably justified in a free and democratic society. It follows that whatever rights are guaranteed by section 35 are guaranteed absolutely. Nevertheless, in determining the nature and scope of those rights, it seems likely that courts will be guided by standards of reasonableness. A second consequence is that section 35 is not subject to the override mechanism embodied in section 33 of the Charter, which permits Parliament and provincial legislatures to suspend the operation of many Charter provisions..$^{3}$ Again, while it is at least arguable that, under section 32, the Charter protects the rights it enshrines only as against governmental acts, not private activities, no such restriction operates as regards section $35 .{ }^{4}$ On the other hand, the guarantee of aboriginal rights is not covered by subsection 24(1), which provides that anyone whose rights under the Charter have been infringed may apply to a court to obtain such remedy "as the court considers appropriate and just in the circumstances." It seems probable, however, that the courts will in any case supply appropriate remedies for the violation of section 35 .

The guarantee of aboriginal rights in section 35 is supplemented by a provision located within the Charter itself that serves to insulate these and other rights from the potential levelling effect of the Charter. Section 25 states:

The guarantee in this Charter of certain rights and freedoms shall not be construed so as to abrogate or derogate from any ab-
Le fait que la présente charte garantit certains droits et libertés ne porte pas atteinte aux droits ou libertés - ancestraux, issus de

3 Subject, arguably, to thie standard laid down in section 1; see Slattery, "Canadian Charter of Rights and Freedoms - Override Clauses under Section 33 - Whether Subject to Judicial Review under Section 1" (1983), 61 Canadian Bar Review 422.

4 See Swinton, "Application of the Canadian Charter of Rights and Freedoms," in Tarnopolsky and Beaudoin, eds., The Canadian Charter of Rights and Freedoms (1982), 41-59. A contrary argument would point to the unqualified language employed in many Charter provisions, and the broad wording of the remedies provision in section 24 . 
original, treaty or other rights or freedoms that pertain to the aboriginal peoples of Canada including

(a) any rights or freedoms that have been recognized by the Royal Proclamation of October 7,$1763 ;$ and

(b) any rights or freedoms that may be acquired by the aboriginal peoples of Canada by way of land claims settlement. traités ou autres - des peuples autochtones du Canada, notamment :

a) aux droits ou libertés reconnus par la Proclamation royale du 7 octobre 1763;

b) aux droits ou libertés acquis par règlement de revendications territoriales.

Under the recent agreement, paragraph $25(\mathrm{~b})$ will be replaced by a new provision, reading:

(b) any rights or freedoms that now exist by way of land claims agreements or may be so acquired. b) aux droits ou libertés existants issus d'accords de revendications territoriales ou ceux susceptibles d'être ainsi acquis.

The Constitution also provides for a constitutional conference attended by aboriginal representatives (section 37). As noted above, this conference has already been held, and so the provision is now spent. However, the new agreement contains a section calling for two further conferences of the same type. ${ }^{5}$ This section does not affect the meaning of the substantive provisions considered above ${ }^{6}$ and will not be discussed here.

The legal effect of the aboriginal rights provisions is governed by section 52 . This states that the Constitution of Canada "is the supreme law of Canada, and any law that is inconsistent with the provisions of the Constitution is, to the extent of the inconsistency, of no force or effect." The same section provides that amendments to the Constitution shall be made only in accordance with the special amending procedures laid down. The effect is to put the Constitution in a position of legal paramountcy. The Act overrides "any law" ("toute autre règle de droit") that is inconsistent with its terms, including both statutes and the common law. The provision has no temporal restrictions; statutes passed at earlier periods are as liable to nullification as those enacted in future, regardless of which body passed them. ${ }^{7}$ Statutes laid

5 Section 37.1.

6 This is explicitly provided in section 37.1(4): "Nothing in this section shali be construed so as to derogate from subsection 35 (1)."

7 The nullification of pre-existing laws operates, of course, only for the future, and not for the period prior to the date when the Constitution came into force. 
down by pre-Confederation Canadian legislatures are covered, as are British statutes extending to Canada ex proprio vigore or by the reception of English law. French law in Quebec is subject to override, whatever its source.

This means that rights recognized in the Constitutio. take effect notwithstanding any contrary provisions of either the common law or statutes, past and future. I will consider later how this general proposition applies to the "existing aboriginal and treaty rights" recognized in section 35 .

The aboriginal rights provisions can be amended only in accordance with Part $V$ of the Constitution. Under the ordinary procedure, laid down in section 38, an amendment requires the approval of Parliament and of sufficient provincial legislatures to account for two-thirds of the provinces and fifty per cent of the population. ${ }^{8}$

It might be thought that the less stringent procedure specified in section 43 could also apply here. The section states:

\footnotetext{
An amendment to the Constitution of Canada in relation to any provision that applies to one or more, but not all, provinces, including
}

(a) any alteration to boundaries between provinces, and

(b) any arnendment to any provision that relates to the use of the English or the French language within a province,

may be made by proclamation issued by the Governor General under the Great Seal of Canada only where so authorized by resolutions of the Senate and House of Commons and of the legislative assembly of each province to which the amendment applies.

Does this section allow aboriginal or treaty rights in a single province to be modified by joint action of Parliament and the relevant provincial legislature? The answer is negative. Section 43 relates only to constitutional provisions that apply to one or

8 The proposed new section 35.1 also requires the convening of a constitutional conference to which aboriginal representatives are invited prior to the amendment of certain constitutional provisions concerning native peoples. 
several provinces. A provision that applies to all provinces cannot be amended under this section, even if the amendment only affects a single province. The English text is, perhaps, slightly ambiguous on this point, although it seems clear enough that the clause "that applies to one or more, but not all, provinces" qualifies the word "provision," and not "amendment." However, the French version is unequivocal, referring to "les dispositions de la Constitution du Canada applicables à certaines provinces seulement."

Thus, the sole constitutional provisions amendable under section 43 are those explictly confined to one or several provinces. An example would be subsection 17(2), which guarantees the use of English or French in the New Brunswick legislature. By contrast, freedom of expression in New Brunswick could not be limited under section 43 , because the provision guaranteeing that freedom applies generally to all the provinces (section 2(b)). It follows that, since the provisions governing aboriginal rights are general in scope, they cannot be amended under section 43 , no matter how limited the amendment is.

It might be contended, to the contrary, that section 35 is a provision "that applies to one or more, but not all, provinces," because not all provinces have subsisting aboriginal rights or treaty rights. This argument fails to distinguish between the scope of a provision and its practical impact. The concrete implications of section 35 may vary considerably from province to province. But in this respect the section is hardly unique. The minority language educational rights set out in section 23 of the Charter have greater significance for certain provinces than others. In both cases, the sections employ language that is general in scope and not restricted in advance to any group of provinces. This factor alone rules out use of section 43 .

This completes my brief survey of the provisions concerning aboriginal rights. I will now return to sections 25 and 35 , and consider their precise scope and legal effects.

\section{2) $S E C T I O N 25$}

a) Scope

As the reader may have already noted, section 25 is worded more broadly than section 35 . Both sections mention aboriginal and treaty rights. However, section 25 also refers to "other rights or freedoms that pertain to the aboriginal peoples of Canada." This catch-all phrase seems to cover any rights whatever that aboriginal peoples enjoy by virtue of their distinctive status. It 
would not, of course, include rights that they possess as ordinary Canadians or in capacities unrelated to native status.

A second difference is that, while section 25 speaks of "rights or freedoms," section 35 mentions only "rights." The disparity, however, seems more verbal than real. Can the drafters have intended to draw a sharp line between, say, treaty provisions conferring "rights" and those granting "freedoms," and to guarantee only the former in section 35 , while protecting both in section 25 ? There would appear to be no reason for doing this. The term "rights," in normal usage, is broad enough to include freedoms, powers, and immunities, and it seems natural to read section 35 in this way. Section 25, being part of the Charter, conforms with the phraseology employed there, and so, like other comparable Charter sections, speaks of both "rights" and "freedoms."9

Of greater interest is the fact that, while section 35 guarantees only "existing" rights, this qualification is not found in section 25. This suggests that it does not matter for the purposes of section 25 when a right was first acquired. Thus, rights gained only after 17 April 1982, when the Constitution came into force, stand to benefit. This conclusion is reinforced by paragraph $25(\mathrm{~b})$, which, as it now stands, speaks of any rights "that may be acquired" by way of land claims settlement. Rights arising in the future are clearly covered. The proposed new paragraph 25 (b) is even more specific, refering to rights that "now exist" by way of land claims agreements or that "may be so acquired." The scope of paragraph (b) is significant because the wording of the section indicates that the rights enumerated in paragraphs (a) and (b) are already included in the general opening reference to "aboriginal, treaty or other rights or freedoms." Thus, that general phrase must be capable of extending to rights arising only in the future.

This brings us to another distinctive feature of section 25 . While section 35 rests content with general references, the earlier section mentions two specific types of rights in paragraphs (a) and (b), namely rights recognized by the Royal Proclamation of 1763 , and, as just noted, rights acquired in land claims settlements. The specific reference to these rights in section 25 could be taken to suggest their exclusion from section 35 , it being silent on the point. But the wording of the two sections militates against this conclusion. As seen above, the rights specifically enumerated in section 25 are already comprised in the formula 
"aboriginal, treaty or other rights or freedoms." It seems probable that rights recognized by the Royal Proclamation of 1763 are "aboriginal rights," while rights acquired under land claims agreements are "treaty rights." If this is the case, then the same rights are also covered in section 35 under the general rubric "aboriginal and treaty rights," unless excluded by the word "existing."

It may be questioned whether section 25 covers land claims settlements made before 17 April 1982 as well as subsequent ones. We have already seen that the current English version of paragraph $25(b)$ mentions settlement rights "that may be acquired," referring primarily to rights arising in the future. The French text refers simply to "droits ou libertés acquis," employing a neutral expression capable of covering rights either past or future. But the question does not turn on the wording of paragraph $25(\mathrm{~b})$ alone. As mentioned above, the provision merely furnishes an illustration of rights already captured by the general opening words. Those words contain no hint of temporal limitation. It follows that if rights gained under land claims settlements are covered by the phrase "aboriginal, treaty or other rights or freedoms" it does not matter whether they were acquired before or after 17 April 1982. The proposed new wording of paragraph 25 (b) makes this perfectly clear, referring to both existing and future rights.

(b) Legal effects

What function does section 25 serve? The answer lies in the fact that certain other provisions of the Charter of Rights, although not referring specifically to native rights, could be interpreted as modifying those rights. Section 15 , for example, provides that everyone is equal before the law and is entitled to the equal protection and benefit of the law without discrimination based on race or national or ethnic origin. This provision could conceivably be read as affecting a range of rights distinguishing native peoples from ordinary Canadians.

Section 25 prevents such an effect, providing that the Charter "shall not be construed" so as to abrogate or derogate from any native rights. This rule of construction is mandatory. Where a Charter right impinges on a section 25 right, the latter must prevail. ${ }^{10}$

Section 25, then, limits the extent to which the other Charter

10 Subject to the terms of section 28 , considered below. 
provisions can adversely affect native rights and freedoms. But it does not establish those rights in a positive fashion. Neither does it sereen them from the impact of ordinary federal and provincial laws, nor of constitutional provisions located outside the Charter.

Finally, it should be pointed out that section 1 of the Charter cannot be used to reduce the insulating effect of section 25 . Section 1 permits certain reasonable limits to be placed on rights guaranteed by the Charter. However, section 25 does not itself guarantee any rights. Rather, it places limits on rights set out elsewhere in the Charter. Those other rights, as limited by section 25, are subject to further limitation under section 1. But they cannot be expanded beyond the boundaries laid down in section 25 by reason of section 1 . The latter section contemplates the limitation, not the extension, of rights guaranteed.

c) Sexual equality

A significant question arises regarding the interaction between section 25 and section 28 . The latter provision states:

Notwithstanding anything in

this Charter, the rights and freedoms referred to in it are guaranteed equally to male and female persons.
Indépendamment des autres dispositions de la présente charte, les droits et libertés qui y sont mentionnés sont garantis également aux personnes des deux sexes.

Does this section qualify the protection afforded by section 25 to native rights? The opening phrase, "notwithstanding anything in this Charter," seems to give the provision precedence over section 25, which does not contain words of parallel strength. The effect is to ensure that the rights mentioned in section 25 , to the extent that they exist, are enjoyed equally by male and female persons. This flows either from the direct application of section 28 to section 25 , or from its indirect application through section 15. I will briefly consider each possibility.

It can be argued that the phrase, "the rights and freedoms referred to in [the Charter]," as used in section 28 , is broad enough to include the aboriginal, treaty and other rights mentioned in section 25 . Section 28 speaks of rights referred to in the Charter, rather than rights guaranteed there. Section 25 , as we have seen, does not guarantee the rights it describes. But plainly it "refers" to them. On this view, section 28 applies directly to section 25 and ensures that any rights enumerated in the latter section, to to the extent that they exist, are equally available to members of both sexes. 
Nevertheless, it could be contended that section 28 extends only to rights actually guaranteed in the Charter, and not to rights merely mentioned there. On this view, the native rights referred to in section 25 would not be covered directly. Even if this interpretation is correct, much the same result will be achieved indirectly through the operation of section 15 , once that section comes into effect in $1985 .{ }^{11}$

Section 15 provides, inter alia, that every individual is equal before the law and has the right to the equal protection and equal benefit of the law without discrimination based on sex. Standing alone, this section presumably prohibits sexual discrimination in the legal rules governing access to and enjoyment of native rights. ${ }^{12}$ Nevertheless, section 25 could arguably be interpreted as preventing this effect, in that it screens native rights from the operation of Charter guarantees. Whatever the merits of this interpretation, section 28 rules it out. That section, as seen above, operates notwithstanding anything else in the Charter, and to that extent curtails the protective effect of section 25. In other words, section 28 ensures that the right to equality before the law set out in section 15 prevents any sexual discrimination in the law governing enjoyment of native rights, notwithstanding section 25 ,

This guarantee of sexual parity appears to be absolute. It is not affected by section 1, which authorizes "reasonable limits" on Charter rights, because section 28 operates notwithstanding anything else in the Charter, including section 1. Moreover, the override mechanism established in section 33 applies only to sections 2 and 7 to 15 , and so cannot be used to supersede a guarantee flowing from section 28 .

The point is one of some significance to native peoples. Membership in aboriginal groups is governed by rules dealing with such factors as marriage, descent, legitimacy, and adoption. Where such rules discriminate between males and females, they would seem invalid under the new Constitution. ${ }^{13}$ Again, any dis-

11 The operation of section is suspended for three years under subsection $32(2)$.

12 Cf. Attomey General of Canada v. Lavell, [1974] S.C.R. 1349 (S.C.C.). The majority decision in that case appears to be based largely on considerations pertaining to the Canadian Bill of Rights, 1960 (Can.), c. 44, that are not applicable to section 15 of the Charter.

13 In particular, section 12 (1) (b) of the Indian Act, R.S.C. 1970, c. I-6, deprives an Indian woman who marries a non-Indian of her Indian status, whereas there is no comparable effect for an Indian man. 
crimination between the male and female members of aboriginal groups as to the nature and extent of native rights enjoyed would appear to be ruled out.

The Charter, then, ensures that any aboriginal, treaty or other rights and freedoms pertaining to aboriginal peoples, insofar as they exist, extend equally to male and female persons. The question arises how this conclusion affects the guarantee of aboriginal and treaty rights found in section 35 . It may be noted that section 28 only covers rights and freedoms referred to in the Charter, and so does not apply directly to section 35 . Nevertheless, as noted previously, section 35 rights are part of the larger group of rights referred to in section 25 . As such, they are already governed by the guarantee of sexual parity found in section 28 .

The proposed new subsection $35(4)$ does no more than spell out this consequence, providing that the aboriginal and treaty rights referred to in subsection $35(1)$ are guaranteed equally to male and female persons. This new provision will not necessarily obviate the need to determine the effect of section 28 on section 25 . The reason is that section 25 refers to a broader range of native rights than section 35 . Thus, even if the right to membership in an Indian band is held not to constitute an aboriginal or treaty right within the meaning of section 35 , it would seem to be one of the "other rights or freedoms" referred to in section 25, and as such would be guaranteed equally to males and females by virtue of section 28 .

\section{3) SECTION 35}

The questions of interpretation presented by section 25 are simple and clear-cut by comparison with those arising under section 35 . As we saw earlier, the latter provision states in subsection (1) that the "existing aboriginal and treaty rights of the aboriginal peoples of Canada are hereby recognized and affirmed." The text refers to two distinct categories of rights, namely "aboriginal rights" and "treaty rights." The second category is narrower than the first. Treaty rights, generally speaking, are rights based on promises made by the Crown regarding native peoples in agreements usually styled "treaties." At least two kinds of agreement arguably are covered by the section. The first type

14 The question whether a document constitutes a treaty within the meaning of section 35 would appear to depend on the nature of the document, and not exclusively on the nomenciature employed in the document itself. 
$m$ i

directly links the Crown and a native group. The second binds the Crown and one or more foreign states, and contains stipulations concerning aboriginal peoples. Prima facie, the section seems broad enough to cover both types. ${ }^{15}$ Here I will deal only with the first group of agreements, usually termed "Indian treaties."

The expression, "aboriginal rights," by contrast, refers to a range of rights held by native peoples, not by virtue of Crown grant, agreement, or legislation, but by reason of the fact that aboriginal peoples were once independent, self-governing entities, in possession of most of the lands now making up Canada. As the word "existing" indicates, section 35 does not restore aboriginal groups to their former position of complete autonomy; neither does it revive their rights to land that have lawfully been extinguished in the past. What it does is recognize that some, if not all, of the rights originally vested in native Canadians have survived the process whereby the Crown gained sovereignty over Canadian territories. Insofar as those rights were not lawfully terminated prior to 17 April 1982, they now enjoy the protection of section 35. I propose to concentrate here on aboriginal rights regarding land, leaving to one side questions relating to selfgovernment, customary law, and cultural and religious rights.

Before considering the scope and effects of section 35 , it is helpful to recall how aboriginal land rights and treaty rights stood before the section was enacted. Two points deserve mention. First, the legal position of both categories of rights was unclear in various ways. Second, these rights were in principle subject to compulsory modification and extinguishment by the acts of a competent legislature. ${ }^{16} \mathrm{I}$ will say a few words about each point.

The existence of aboriginal land rights has been recognized by Canadian courts for some time, but not in such a fashion as to

15 Cf. Fransis v. The Queen, [1956] S.C.R. 618 (S.C.C.), at 631, where two members of a seven-man court (Kellock and Abbott JJ.) expressed the obiter opinion that the term "treaty," as used in what is now section 88 of the Indian Act, R.S.C. 1970, c. I-6, did not cover an internationai treaty containing a stipulation favouring Canadian Indians. Even if this construction is correct, it would seem that a more generous interpretation should prevail in respect to a constitutional provision drafted with a broad remedial intent. See: Lysyk, "The Rights and Freedoms of the Aboriginal Peoples of Canada," supra, note 1, at 485 .

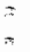

16 This did not, of course, hold true where those rights had been recognized or confirmed in a constitutional instrument binding on the legislatures concerned. See reference in note 26 , infra. 
put the matter beyond all conceivable doubt. ${ }^{17}$ The leading case is now Calder v. Attorney-General of British Columbia (1973), 34 D.L.R. (3d) 145 (S.C.C.). There, three judges of the Supreme Court of Canada positively affirmed that the aboriginal land rights of the Nishga people survived the Crown's acquisition of sovereignty over British Columbia, invoking a principle of presumptive continuity and the common law doctrine of Indian title. ${ }^{18}$ Another three judges seemingly accepted this view, if in less explicit terms, but held that in any case the aboriginal rights asserted had been extinguished by legislation before British Columbia entered Confederation. ${ }^{19}$ The case as a whole has been interpreted as upholding the existence of aboriginal land rights at common law, and an attentive reading of the judgments supports this view..$^{20}$ But the statements of Mr. Justice Judson, speaking for the second group, lack clarity and precision, and are perhaps open to other interpretations.

There has also been uncertainty about the precise character of aboriginal land rights. In St. Catherine's Milling and Lumber Co. v. The Queen (1888), 14 A.C. 46, the Privy Council described the land tenure of Indians under the Royal Proclamation of 1763 as "a personal and usufructuary right, dependent upon the good will of the Sovereign." They explained that the Crown held "a substantial and paramount estate, underlying the Indian title, which became a plenum dominium whenever that title was surrendered or otherwise extinguished."21 Thus, at Confederation, the Crown held an underlying title to Indian lands covered by the Royal Proclamation. Where Indian lands fell within the limits of a province, the Crown's title was held for the benefit of the province, subject to an "Interest other than that of the Province"

17 For early judicial discussion of aboriginal land rights, see: Connolly v. Woolrich (1867), 11 L.C. Jur. 197 at 204-207 (Que. S.C.), upheld on appeal sub nom. Johnstone v. Connolly (1869), 1 R.L.O.S. 253 at 356-357 (Que. Q.B.) ; Church v. Fenton (1878), 28 U.C.C.P. 384 at 388 (Ont. C.P.) ; St. Catherines's Milling and Lumber Co. v. The Queen (1885), 10 O.R. 196 (Ont. Ch.) ; (1886), 13 O.A.R. 148 (Ont. C.A.); (1887), 13 S.C.R. 577 (S.C.C.) ; (1888), 14 A.C. 46 (P.C.). For a recent treatment, see $R$. v. Secretary of State for Foreign and. Commonwealth Affairs, [1982] 2 All E.R. 118 (C.A.) per Lord Denning M.R. at 123.

18 Per Hall J. (Spence and Laskin JJ. concurring) at 190-203, 208-211.

19 Per Judson J. (Martland and Ritchie JJ. concurring) at 150-152, 156.

20 See, e.g., Hamlet of Baker Lake v. Minister of Indian Affairs and Northern Development, [1980] 1 F.C. 518 (F.C.T.D.) at 556-557; Lysyk, "The Indian Title Question in Canada," supra, note 1, at 452-467.

21 At 54-55. 
within the meaning of section 109 of the British North America Act, 1867.22 Upon the surrender of the Indian title, the full benefit of the lands affected would become available to the province.

This case decided a very important question, namely whether the benefit of an Indian land cession within a province falls to the federal or provincial government. But it left uncertainty about the exact nature of Indian title. Was it a precarious right, held at the pleasure of the Crown and revocable by prerogative act? Or was it maintainable at law against the Crown, unless extinguished by statute or voluntary surrender $?^{23}$ In any case, did aboriginal land rights correspond in character to rights held under the Royal Proclamation of 1763? In truth, these questions did not arise for resolution in the St. Catherine's case, and so the judgment's ambiguity on these points is not surprising. Subsequent cases have not provided much further illumination, although there has been much quotation of the phrases employed by the Privy Council. On this point, Mr. Justice Judson aptly remarked in the Calder case that, in considering the character of Indian title, "it does not help one in the solution of this problem to call it a "personal and usufructuary right." "24

What is clear is that aboriginal land rights, like other property rights, were in principle extinguishable by clear statutory provisions enacted by a competent legislature, unless those rights were protected by constitutional provisions binding on the legislature in question..$^{25}$ It is less evident which Canadian legislatures were competent to extinguish aboriginal title under the British North America Act, $186 \%$, and how far the powers granted there were limited by the terms of other constitutional instruments concerning aboriginal lands. ${ }^{26}$ So far as the British North Amer-

22 Now confusingly renamed the Constitution Act, $186 \%$, by virtue of the Constitution Act, 1982, Schedule, Item 1. The original title is used in this paper.

23 For varying views, see Calder v. Attorney-General of British Columbia (1973), 34 D.L.R. (3d) 145 (S.C.C.), per Judson J. at 156; per Hall J. at 208-209.

24 Ibid., at 156.

25 On the susceptibility of aboriginal title to legislative overxide, see: Calder v. Attorney-General of British Columbia (1973), 34 D.L.R. (3d) 145 (S.C.C.), per Judson J. at 159-160, per Hall J. at 208-210; Hamlet of Baker Lake $v$. Minister of Indian Affairs and Northern Development, [1980] 1 F.C. 518 (F.C.T.D.) at 566-569.

26 For an excellent review of the constitutional terms governing Rupert's Land and the old North-Western Territory and the boundaries of those territories, see: McNeil, Native Claims in Rupert's Land and the North- 
ica Act, $186^{\circ}$ is concerned, it can plausibly be argued that federal authorities have sole jurisdiction to extinguish aboriginal land rights, by virtue of subsection 91(24) of the Act, which confers on the Dominion Parliament exclusive authority over "Indians, and Lands reserved for the Indians." The Privy Council in the St. Catherine's case, held that this provision was broad enough to include all lands reserved, upon any terms or conditions, for Indian occupation, and hence covered lands held by Indians under the Royal Proclamation of 1763.27 Since the Proclamation recognized but did not create aboriginal land rights (a view now buttressed by the wording of section 25 of the Charter), ${ }^{28}$ it can be inferred that aboriginal land rights generally are within federal jurisdiction. ${ }^{29}$ This conclusion is supported by past Dominion

Western Territory: Canada's Constitutional Obligations (University of Saskatchewan Native Law Centre, 1982); McNeil, Native Rights and the Boundaries of Rupert's Land and the North-Western Territory (University of Saskatchewan Native Law Centre, 1982). For discussion of the question of whether the Royal Proclamation of $1 \% 63$ was binding on Canadian legislatures, see Slattery, Land Rights of Indigenous Canadian Peoples, supra, note 1,315-319; and $R$. v. Secretary of State for Foreign and Commonwealth Affairs, [1982] 2 All E.R. 118 (C.A.), at 124, 125, where Lord Denning M.R. said that the Proclamation "was equivalent to an entrenched provision in the constitution of the colonies in North America" and continued to be constitutionally binding on the Dominion and provincial legislatures even after Confederation.

27 (1888), 14 A.C. 46 at 59.

28 Subsection 25 (a) refers to "any rights or freedoms that have been recognized by the Royal Proclamation of October 7, 1763" (emphasis added). See: R. v. White and Bob (1964), 50 D.L.R. (2d) 613 (B.C.C.A.) per Norris J.A. at 630, 636; Calder v. Attorney-General of British Columbia (1973), 34 D.L.R. (3d) 145 (S.C.C.) per Hall J. at 204-205, and also the comments of Judson J. at 152,$156 ; R$. V. Isaac (1975), 13 N.S.R. (2d) 460 (N.S.S.C. App. Div.) per MacKeigan C.J. at 478; Hamlet of Baler Lakie v. Minister of Indian Affairs and Northern Development, [1980] 1 F.C. 518 (F.C., Tr. Div.) at 555-557. See also discussion in Slattery, Land Rights of Indigenous Canadian Peoples, supra, note $1,217-230$.

29 In a brief oral judgment in R. v. Derriksan (1976), 71 D.L.R. (3d) 159 (S.C.C.), Laskin C.J. held that the federal Fisheries Act, R.S.C. 1970, c. F-14, and Regulations thereunder had the effect of limiting the exercise of an asserted aboriginal right to fish in British Columbia. The court apparently did not find it necessary to consider the scope of subsection 91 (24) of the British North America Act, 186\%, presumably because the legislation could be justified under subsection 91(12) which grants Parliament power over coastal and inland fisheries. The brevity of the judgment makes it difficult to extract from the case itself pro- 
practice in negotiating land surrender treaties, and the recognitior given to these treaties by the courts. ${ }^{30}$

If indeed aboriginal lands generally constitute "lands reserved for the Indians" under section 91(24), it seems to follow that the provincial legislatures have no intrinsic authority to nullify aboriginal title. Otherwise, they would be able to convert Indian lands into non-Indian lands and thus unilaterally appropriate the very subject-matter of a federal power. By parallel, it would not be open to provincial legislatures to deprive Indians of Indian status and thus withdraw them from federal jurisdiction. This does not necessarily mean, of course, that the provinces are utterly debarred from regulating the exercise of aboriginal land rights by statutes of general application. ${ }^{31}$

Treaty rights were bedevilled with similar ambiguities. Although courts were not slow to credit Indian treaties with the effect of extinguishing aboriginal title in favour of the Crown, ${ }^{32}$ they were less quick to indicate how far the rights conferred on Indians by these treaties were binding on the Crown and enforc-

positions of more general relevance. Nevertheless, in Kruger and Manuel v. The Queen (1977), 75 D.L.R. (3d) 434 (S.C.C.), Dickson J., speaking for the court, stated as follows at 443: "Assuming, without deciding, that the theory of aboriginal title as elaborated by Hall J., in Calder et al. v. A.-G.B.C.... is arailable in respect of present appellants it has been conclusively decided that such title, as any other, is subject to Regulations imposed by validly enacted federal laws: Noll Derriksan v. The Queen (a recent decision of this Court not yet reported)."

30 Any general justification of the land surrender treaties concluded by the federal government since 1867 apparently must rest on one of two premises: either (a) subsection 91(24) of the British North America Act, 1867 extends to any aboriginal lands whatever, including any not covered by the Royal Proclamation of 1763; or (b) the Proclamation itself covers virtually the whole of Canada from the Quebec-Ontario border westward. See also the documents discussed in Lysyk, "The Indian Title Question in Canada," supra, note 1, 463-465.

31 See discussion in Kruger and Manuel v. The Queen (1977), 75 D.L.R. (3d) 434 (S.C.C.). The Supreme Court held there that an asserted aboriginal right to hunt outside of a reserve was subject to provincial game laws, either by virtue of the referential incorporation of the enactment as fecieral legislation under section 88 of the Indian Act, R.S.C. 1970 , c. I- 6 , or alternately by the enactment's application $e x$ proprio vigore. The Court found it unnecessary to determine which was the true source of authority.

32 See, for example, St. Catherine's Milling and Lumber Co. v. The Queen (1888), 14 A.C. 46 (P.C.) at 60. 
ible in the courts. ${ }^{33}$ It was recognized that the federal Parliament had the power to enact legislation inconsistent with the terms of Indian treaties. ${ }^{34}$ However, provincial legislation violating such terms has been struck down..$^{3 \overline{ }}$

The question is how far section 35 has altered this state of affairs. Several facts should be noted. Section 35 is present in the Constitution as the direct result of prolonged and vigorous campaigns by native groups. When the Special Joint Committee on the Constitution agreed unanimously to insert the section, the occasion was treated by all parties as one of historic significance. The later deletion of the section, as the result of the federalprovincial accord of November 1981, caused a sharp reaction among native Canadians. Intensive lobbying and public demonstrations led to its reinstatement, in a slightly amended form. These facts suggest that section 35 was intended to operate in a. remedial fashion. It seems unlikely, prima facie, that the provision left matters in their original state. This presumption, nevertheless, must yield if necessary to the words employed in the section, which will now be reviewed in greater detail. I will begin with the section's affirmation that certain rights are hereby "recognized and affirmed." What exactly does this mean?

a) The effect of "recognition" and "affirmation"

Some preliminary guidance is furnished by standard definitions of the words used. The term "recognize" is defined in the Concise Oxford Dictionary in this way:

Acknowledge validity or genuineness or character or claims or existence of [a thing or person], accord notice or consideration to [a thing or person].... ${ }^{36}$

An expanded definition appears in the Oxford English Dictionary:

To acknowledge by special notice, approval or sanction; to treat as valid,

33 For recent discussions, see Town of Hay River v. The Queen, [1980] 1 F.C. 262 at 265 (F.C.T.D.) : Pawis v. The Queen, [1980] 2 F.C. 18 (F.C.T.D.).

34 Sikyea v. The Queen, [1964] S.C.R. 642 (S.C.C.), upholding the judgment of the Northwest Territories Court of Appeal, (1964), 43 D.L.R. (2d) $150 ;$ R. v. George (1966), 55 D.L.R. (2d) 386 (S.C.C.).

35 R. v. White and Bob (1965), 52 D.L.R. (2d) 481 (S.C.C.), affirming (1964), 50 D.L.R. (2d) 613 (B.C.C.A.). and applying the terms of what is now section 88 of the Indian Act, R.S.C. 1970, c. I-6.

36 Fowler and Fowler, eds., The Concise Oxford Dictionary of Current English, 5th ed. (1964), 1033. 
as having existence or as entitled to consideration; to take notice of (a thing or person) in some way. 37

Two alternative meanings seem possible in the context of section 35. Either the provision means that the rights referred to are "hereby acknowledged as valid," or it affirms only that the rights are "hereby taken note of." The meaning of a word depends much on the context. Here we have a constitutional provision, enacted with some éclat, and understood to be broadly remedial. The legal validity and status of the rights it mentions have hitherto been attended by uncertainty. It seems natural therefore to read the section as stating that the rights are "acknowledged to be valid." The alternative, weaker meaning would drain the section of legal significance. As between an interpretation that gives a legal provision legs to walk on and one that cripples it, the former should ordinarily be preferred.

This construction derives support from Black's Law Dictionary, which states that "recognition" is equivalent to "ratification" and "confirmation." 38 Again, in British Pacific Trust Co. v. Baillie (1914), 7 W.W.R. 17, the British Columbia Supreme Court held that the word "recognize," as used in a provision stating that courts "shall recognize and take notice of all equitable estates, titles and rights. ..," was imperative and meant "give effect to." 39

But the word "recognized" does not stand alone in section 35;

" it must be read as part of the phrase "recognized and affirmed." The Concise Oxford Dictionary gives the following applicable meanings for "affirm":

Assert strongly, aver; make formal declaration...; (Law) confirm, ratify, (judgement). 40

The same usages are more fully explained in the Oxford English Dictionary:

2. Law. To confirm or ratify (a judgment, law)....

3. ... To make a statement and stand to it; to maintain or assert strongly, to declare or state positively, to aver. 41

Here again we are faced with a choice. Section 35 , in providing

37 The Oxford English Dictionary (1938; reissued 1961), VIII, 253, 4th meaning.

38 Black's Law Dictionary, 5th ed. (1979), 1143.

39 At 21.

- 40 Supra, note 36 , at 22.

41 Supra, note 37, I, at 157. 
that certain rights are "affirmed," could mean that they are "confirmed and ratified," or alternately that they are "strongly asserted." According to the dictionaries, the first meaning normally obtains in a legal context. It seems reasonable to think, prima facie, that section 35 uses the word in its specific legal sense.

The French version of the section reinforces this conclusion. It employs "confirmés" as the equivalent of the English "affirmed." The choice of the former term is telling, because several alternatives were available. Harrap's Standard French and English Dictionary states that "affirm" may be rendered in French in the following ways:

1. Affirmer, soutenir (that, que)....

2. Jur: Confirmer, homologuer (un jugement). 42

Thus, the specific juridical term "confirmer" was preferred by the Constitution's drafters over the more generalized "affirmer." Harrap's also says that the French verb "confirmer" has the following applicable meanings in English:

To confirm (news, judgment, etc.). [Confrrmer] un traité, to ratify a treaty....43

Sigrificantly, the dictionary does not mention "affirm" as an English equivalent for "confirmer," presumably because "confirm" and "ratify" are less ambiguous terms. It follows that "affirmed" must be used in section 35 in its specific legal sense of "confirmed" or "ratified"; only then does it have a common core of meaning with the French term "confirmer."

Legal dictionaries provide further evidence on this point. Black's Law Dictionary states that "affirm" means:

To ratify, make firm, confirm, establish, reassert....44

Jowitt's Dictionary of English Law indicates that "affirm" is used in three senses, the first two of which are relevant here:

(1) With regard to contracts, where a contract is voidable, if the party at whose option it is voidable elects to waive his right to avoid the contract and elects to carry out the contract he is said to affirm it; ...

(2) With regard to courts, an appellate court is said to affirm the judgment of a court below if it upholds that judgment. $4 \overline{5}$

42 Mansion, ed., Harrap's Standard French and English Dictionary (1961), II, 20.

43 Ibid., I, 181.

44 Supra, note 38 , at 55 .

45 Burke, ed., Jowitts Dictionary of English Law, 2nd ed. (1977), 1, 69. 
An interesting feature of these definitions is the close affinity noted between the terms "affirm" and "confirm," an affinity already attested to by the English and French versions of section 35. There is a wealth of authority on the meaning of the second term. A good starting point is Black's Law Dictionary, which defines "confirm" as follows:

To complete or establish that which was imperfect or uncertain; to ratify what has been done without authority or insufficiently. To make firm or certain; to give new assurance of truth or certainty; to put aside past doubt; to give approval to. 46

Stroud's Judicial Dictionary cites several cases dealing with the confirmation of wills, and goes on to observe:

(3) So, semble, to "confirm" a document will frequently mean, to give it life which previously it never had, e.g. if the document is invalid, either intrinsically or extrinsically, and is subsequently "confirmed" by another document which would have validly accomplished the objects of the prior document, such prior document will be vivified and its professed objects will be made effectual (Carver v. Richards, 29 L.J. Ch. 357; Morgan v. Gronow, L.R. 16 Eq. 1).

(4) But, generally, "a 'confirmation' is the conveyance of an estate or right that one hath in or unto lands or tenements to another that hath the possession thereof, or some estate therein; whereby a voidable estate is made sure and unavoidable, or whereby a particular estate is increased and inlarged" (Touch, 311, eiting Termes de la Ley, and Co. Litt. 295 b. ..).47

The first meaning seems particularly apposite for treaties and other documents of uncertain validity and effect. The second meaning has interesting implications for aboriginal land rights, because these have sometimes been viewed as merely precarious rights, voidable at the pleasure of the Crown.

An illustration of the latter meaning is provided by Byers $\mathrm{v}$. - $W a-W a-N e$ (1917), 169 P. 121 (Oregon S.C.). In 1870, the agent in charge of an Indian reservation issued a permit to the predecessors of Byers to construct a ditch across the reservation to draw water from an adjacent river. The permit was subject to the express condition that "no permanent rights shall attach or become vested," and that use of the ditch "shall be subject to the control of and to be discontinued at the pleasure of the department [of the Interior]." In 1885, Congress enacted a statute providing, inter alia, that the water right in question was "con-

46 Supra, note 38 , at 270 .

47 James, ed., Stroud's Judicial Dictionary of Words and Phrases, 4th ed. (1971), I, 548. 
firmed and continued." The effect of this Act was disputed in the case. Byers argued that it constituted a grant of the water right. On the other side, it was contended that the Act, like the original permit, conferred no more than a revocable license to use the water.

The court considered that the question turned in part on the legal significance of the word "confirmed," and cited various authorities on the point. Thus in Turk v. Skiles, 45 W.Va. 82, 30 S.E. 234 at 235, it was said:

Here is the word "confirm." It has a legal force under the law of conveyance.... Lord Coke defines it [a confirmation] to be: "A conveyance of an estate or right in esse, whereby a voidable estate is made sure and unavoidable, or a particular estate increased." 2 Lomax Dig. 101... . To make sure a voidable estate is the proper office of confirmation. 2 Minor, Inst. 717.

The court also referred to Missouri Co. v. Ransom, 15 Tex. Civ. App. 689, 41 S.W. 826 at 830, where the court stated: "A confirmation is making firm what was before infirm." Again, in Langdeau v. Hanes (1874), 21 Wall. 521 at 530, 22 L.Ed. 606, it was said:

A legislative confirmation of a claim to land is a recognition of the validity of such claim, and operates as effectively as a grant or quitclaim from the government.

In the light of these and other authorities, held the court, the legislative intent embodied in the Act of 1885 was clear. Whereas the original water right under the permit of 1870 was held by a precarious tenure, the Act changed this:

This right was infirm and Congress confirmed it. That which they had enjoyed by sufferance became theirs of right. A revocable license became a grant from the sovereign. ${ }^{48}$

What conclusions emerge from this survey? When section 35 states that existing aboriginal and treaty rights are "hereby recognized and affirmed," it seems to mean that they are formally acknowledged as valid in law and rendered sure and unavoidable. Only "existing" rights are put in this position. But if "existing" is taken to denote only rights that are already valid, indefeasible and enforceable at law, the section would be reduced to an affirmation that legally valid rights are hereby acknowledged to be legally valid. It seems evident that the word "existing" must be 
understood in a less restrictive sense if section 35 is to be read in a meaningful way. As I will argue later, "existing" serves to exclude rights arising after 17 April 1982.49 It also rules out any aboriginal or treaty rights that had been lawfully extinguished prior to that date. However, to the extent that such rights were not extinguished, they still existed, and were validated and placed on a firm legal footing by the new Constitution.

The American case of General Agricultural Corp. v. Moore (1975), 534 P.2d 859 (Mont. S.C.) is suggestive on this point. At issue was the meaning of a clause found in the Montana Constitution, which took effect on 1 July 1973. The provision contains language similar to that found in section 35 :

All existing rights to the use of any waters for any useful or beneficial purpose are hereby recognized and confirmed. (emphasis added)

In 1972, before the Constitution came into force, plaintiff filed a petition seeking to appropriate waters from a stream in accordance with an existing Montana statute. While the action was pending, the statute was repealed. The new Act substituted a novel procedure for the appropriation of water rights, effective 1 July 1973, the same day that the new Constitution was to come into force. The court accepted that, under ordinary circumstances, the repeal of the statute would terminate all pending proceedings taken under it. The question was whether the plaintiff's pending action amounted to an "existing right to the use of any waters" within the meaning of the Constitution, so as to allow the action to continue, despite the repeal of the governing statute.

The court held that the constitutional provision was self-executing, in the sense that it could be given effect to without the aid of any further legislation. The action commenced by the plaintiff amounted to a priority in the appropriation of water that was a valuable right, and came into existence in 1972. As such it was an existing right to the use of water within the meaning of the Constitution. The court commented:

The filing of a petition... is the first step leading to "use", it being an integral part of putting water to public and beneficial use. Limiting "use" to perfected or actual "use" would nullify the existing right of priority created by the flling. 50

The defendants had contended that the repeal of the governing

- 49 Subject to the terms of the proposed new subsection $35(3)$. 50 At 863. 
statute took effect before the new Constitution came into force, so that the plaintiff had no "existing" right capable of being recognized and confirmed. But the court held that the relevant constitutional provision expressed an intent to the contrary. The Constitution constituted "fundamental law to which all other laws must yield," and hence took priority. ${ }^{51}$

There are, of course, significant differences between the constitutional clause considered here and section 35 of the Canadian Constitution. It is interesting, nevertheless, to observe how broadly the court is prepared to construe the phrase "existing rights" in order to ensure that the overall intent of the provision is carried out, holding that it includes merely incipient as opposed to fully perfected rights.

To sum up, the evidence considered above appears to support a number of general propositions. First, insofar as there remained any doubts regarding the soundness of the doctrine of aboriginal title in Canadian law, or the validity of Indian treaties as a class, those doubts are now dissipated..$^{52}$ It can no longer be questioned, in the face of section 35, that aboriginal land rights and treaty rights are legal entities, and not mere political or moral rights, or claims on the Crown's favour. Second, to the extent that aboriginal land rights or treaty rights were precarious rights, revocable at the Crown's pleasure, they are now indefeasible. The confirmation of those rights in section 35 "operates as effectually as a grant or quit-claim from the government." Third, where procedural barriers existed to the assertion of aboriginal or treaty rights those obstacles are now removed. The rights conferred in section 35 are not merely theoretical, but fully capable of assertion and enforcement in the courts. In other words, the provisions of the section are "self-executing."

b) The entrenchment of aboriginal and treaty rights

Before the new Constitution was enacted, aboriginal and treaty rights were in principle subject to modification by legislation passed by a competent legislature.53 Has this position now changed? The answer depends on the correct interpretation of section 52 of the Constitution as it applies to section 35 . Subsection $52(1)$ provides:

51 At 863-864, quoting 16 C.J.S. Constitutional Law \$§ 14-16.

52 of course, the validity of any particular alleged treaty can still be attacked on grounds such as lack of consent, fraud, etc.

53 subject to any limitations imposed by constitutional instruments, as mentioned supra, note 26 . 
The Constitution of Canada is the supreme law of Canada, and any law that is inconsistent with the provisions of the Constitution is, to the extent of the inconsistency, of no force or effect.
La Constitution du Canada est la loi suprême du Canada; elle rend inopérantes les dispositions incompatibles de toute autre règle de droit.

Suppose that a treaty right covered by section 35 is explicitly nullified by a federal statute passed in 1985 . The legislation is in other respects valid. The only issue is whether sections 35 and 52, acting together, render it inoperative. Is the statute "inconsistent with the provisions of the Constitution"? If it is, section 52 sterilizes the offending parts. On the one hand, we have a constitutional provision that recognizes and affirms the treaty right in question, and so confirms it as a valid and enforceable right. On the other hand, we have a statute purporting to abolish that right. Under the first provision, the right is valid; under the second, it is invalid. There seems little doubt an inconsistency exists. It follows that the statute is inoperative for repugnancy to the Constitution.

The same would appear to hold true even if the statute in question provides generous monetary compensation for the extinguishment of the treaty right. What the Constitution guarantees is the right itself. It does not authorize the replacement of that right by something supposed to represent its monetary equivalent. Not all rights can be reduced to a simple cash value. Had the Constitution contemplated that this substitution might be made, clear language would have been employed.

Legislation that renders a treaty right ineffective in some respect, without purporting to abolish it, would likewise be void. Section 35 ensures that the rights named there remain fully operable. A statute that directly impedes the exercise of a constitutional right is inconsistent with that right and consequently fails.

These conclusions are supported by an observation made by Lord Denning of the English Court of Appeal in a case brought by certain native Canadian groups to block the enactment of the new Constitution by the United Kingdom Parliament.54 Lord Denning remarked:

It seems to me that the Canada Bill itself does all that can be done to protect the rights and freedoms of the aboriginal peoples of Canada. It entrenches them as part of the constitution, so that they cannot be

$54 R$. v. Secretary of State for Foreign and Commonwealth Affairs, [1982] 2 All E.R. 118 at 129 (C.A.). 
diminished or reduced except by the prescribed procedure and by the prescribed majorities.

Thus, the only method whereby rights recognized in section 35 can be abridged without the consent of their holders is by constitutional amendment under section 38 of the Constitution, which requires the assent of Parliament and of provincial legislatures accounting for two-thirds of the provinces and fifty percent of the total population. ${ }^{55}$ This requirement is unlikely to place a strait-jacket on the amendment of section 35, since none of the legislatures concerned have a significant electoral interest at stake. Native groups have objected to the constitutional provisions on this very ground, asking for a veto on amendments affecting them. The recent Constitutional Conference agreed on a compromise formula requiring that proposed amendments concerning native rights first be discussed at a First Ministers' Conference attended by aboriginal representatives. ${ }^{56}$

What is less clear is whether sections 35 and 52 would prevent the modification or extinguishment of aboriginal and treaty rights by the voluntary act of the native people concerned. Would it be possible, for example, for a native people to surrender to the Crown their aboriginal rights to certain lands without the need for a constitutional amendment? Is the voluntary termination of a specific right covered by section 35 inconsistent with the provisions of that section within the meaning of section 52 ? The question is of some importance. It determines whether land claims settlements can be effected by agreement coupled with ordinary legislation or would require a constitutional amendment.

There is good reason to think that the Constitution does not rule out the voluntary modification of rights covered by section 35. The purpose of that section, it can be argued, is to protect the rights of aboriginal peoples from external invasion and sup-

55 See discussion supra, at note 8.

56 The proposed new section reads as follows:

35.1 The government of Canada and the provincial governments are committed to the principle that, before any amendment is made to Class 24 of section 91 of the Constitution Act, 1867, to section 25 of this Act or to this Part,

(a) a constitutional conference that includes in its agenda an item relating to the proposed amendment, composed of the Prime Minister of Canada and the first ministers of the provinces, will be convened by the Prime Minister of Canada; and

(b) the Prime Minister of Canada will invite representatives of the aboriginal peoples of Canada to participate in the discussions on that item. 
pression. The section is not meant, as it were, to protect native peoples from themselves. There is no apparent reason why a total of seven provinces should have to sanction a voluntary surrender of rights, as the amending formula in section 38 would require. Where a particular surrender only concerns land in a single province, what interest can other provinces claim in the transaction sufficient to justify the right to veto it? Again, in what way would broad provincial involvement serve to protect the interests of native people themselves? Unless cogent reasons to the contrary can be suggested, the Constitution is best interpreted as allowing for the voluntary modification of rights covered by section 35 .

I conclude, then, that rights recognized in section 35 are immune from infringement by ordinary legislation, but may be altered with the consent of the native peoples concerned. The first branch of this conclusion, nevertheless, might be challenged on the following ground. Both aboriginal and treaty rights were in principle subject to legislative abridgement prior to the Constitution's enactment. Section 35 recognizes those rights only in their "existing" state. Their position is neither improved nor worsened. They carry with them all existing benefits and liabilities, including a liability to legislative override. If a Canadian legislature was able to curtail aboriginal or treaty rights before the new Constitution came into force, it is still competent to do so.

This argument must overcome several obstacles. We have already seen that the phrase "recognized and affirmed" in section 35 signifies that the rights in question, even if previously revocable, are thereby rendered sure and unavoidable. The assertion that the section does nothing to improve the position of these rights is therefore suspect.

The argument also fails to distinguish between characteristics peculiar to the rights in question and those shared with other rights. Before the new Constitution was enacted, Canadian legislatures were generally supreme within their respective spheres and so could alter or abrogate any rights falling under their jurisdiction. The susceptibility of native rights to legislative erosion was something held in common with most other rights, including ordinary rights of private property. It resulted from a general constitutional principle rather than from a defect particular to the rights in question. The effect of the new Constitution is precisely to qualify that general principle and to place the rights recognized therein beyond the reach of regular legislation. If the rights covered by section 35 could be nullified by or- 
dinary statute, it is hard to imagine why they were inserted in the Constitution. What distinguishes the Constitution trom other enactments is the position of paramountcy that it occupies and its relative immunity to legislative change. Yet the argument suggests in effect that section 35 could be eviscerated by a normal federal statute stating that "the existing aboriginal and treaty rights of the aboriginal peoples of Canada are hereby extinguished." This conclusion is difficult to square with the fact that the section itself cannot be modified except under the amending formula. Why bolt the back door when the front door is missing?

Interesting points of comparison are furnished by certain provisions of the South African and Australian Constitutions. The South Africa Act, ${ }^{57}$ passed by the United Kingdom Parliament in 1909, effected a legislative union among several existing British colonies in Southern Africa and laid down a Constitution for the new Union of South Africa. Section 144 of the Act provides as follows:

Any officer of the public service of any of the Colonies at the establishment of the Union who is retained in the service of the Union or assigned to that of a province shall retain all his existing and accruing rights .... (emphasis added)

The wording, then, has similarities with that used in section 35 of the Canadian Constitution. But an important difference between the two Acts must be noted. The South Africa Act provides in section 152 that, with a few exceptions not germane here, the Union Parliament may by ordinary statute repeal or alter any of the provisions of the Act, including section 144.

The effect of section 144 was considered in Noble and Barbour v. South African Railways and Harbours, [1922] A.D. 527. ${ }^{58}$ The plaintiffs were pre-Union employees of the Cape of Good Hope Government who became servants of the South African Government at the establishment of the Union. They asserted that prior to the Union they held various rights by virtue of regulations made under a Cape statute of 1895 , and that these rights were protected by section 144 of the South Africa Act. The question was in part whether the asserted rights could subsequently be affected by regulations framed under a Union statute of 1912. On this point, the trial judge held:

It was not intended by the South Africa Act to confer upon the holder 
of a right a greater right than he had at the taking effect of Union. If the colony which he served had the power by statute to reduce or abrogate his statutory right, that power passed to the successors of the Colonial Legislature, namely, the Union Parliament. If the colonial authority which framed regulations had the power of repealing, altering or amending such regulations, that power passed to the successor of the colonial authority. 59

By the Cape statute of 1895, the Cape Governor had held the power to amend regulations made thereunder. Therefore, reasoned the judge, when the plaintiffs entered the Union service, they took with them their existing privileges subject to the right of the Union Governor-General to repeal or amend the regulations conferring those privileges.

When the case went to appeal, this reasoning was rejected. The Appellate Division held that, after the Union, any rights protected by section 144 could be varied only by the Union Parliament and not by the Governor-General, even if the rights were originally created by regulation, not statute. Once such rights fell under the protection of section 144, they ceased to be subject to the old rule-making machinery that created them. They could only be varied thereafter by new machinery created by or under the South Africa Act. The Union Parliament derived the power to abrogate pre-Union rights, not from its position as successor to the various local legislatures, but from section 152 of the South Africa Act. As seen above, that section provided that the Union Parliament might amend most provisions of the South Africa Act itself, including section 144. It followed that any rights incorporated into section 144 could likewise be taken away by or under the authority of the Union Parliament. ${ }^{60}$ The court stated:

I cannot think that the jurisdiction of the Governor-General-in-Council as successor to the Cape Governor-in-Council was unaffected by sec. 144 and that without further legislation he could immediately after Union have interfered by regulation with rights protected by that clause. The sole power so to interfere was in the Union Parliament. ...61

In effect, the court held that the only authority capable of affecting the "existing and accruing rights" preserved by section 144 of the South Africa Act was the same authority constitutionally empowered to amend section 144 itself. That authority, as specified in section 152 of the Act, was the Union Parliament. The fact that the rights recognized in section 144 had hitherto

59 At 537.

60 At $536-538$.

61 At 538. 
been subject to variation by regulations issued by the Governor did not affect the position prevailing after the Union.

The differences between the South African Constitution and our own caution us against facile comparisons. Nevertheless, the Noble case tends to support the interpretation presented here. The only way in which rights recognized in section 35 of the Canadian Constitution can be varied without consent is by following the procedure laid down for the amendment of section 35 itself. This conclusion is not affected by the fact that prior to the enactment of the new Constitution those rights were in principle modifiable by ordinary legislation.

Further parallels are provided by the Commonwealth of Australia Constitution Act. ${ }^{62}$ Enacted by the United Kingdom Parliament in 1900, this statute establishes a federal union among various British colonies on the Australian continent. The Act contains a provision prefiguring that embodied in the South Africa Act. Section 84 states in part:

When any department of the public service of a State becomes transferred to the Commonwealth, all officers of the department shall become subject to the control of the Executive Government of the Commonwealth.... Any such officer who is retained in the service of the Commonwealth shall preserve all his existing and accruing rights.... (emphasis added)

This provision should be read together with section 52 of the Constitution, which states:

The Parliament shall, subject to this Constitution, have exclusive power to make laws for the peace, order, and good government of the Commonwealth with respect to - ... (ii) Matters relating to any department of the public service the control of which is by this Constitution transferred to the Executive Government of the Commonwealth....

By contrast with the South Africa Act, the Australian Constitution does not allow for the amendment of either section by ordinary statute; a special amending procedure must be followed. To this extent, then, section 84 is "entrenched." What the Constitution fails to make clear, however, is whether the existing rights of a public servant transferred to the Commonwealth are protected by section 84 from abridgement by subsequent Commonwealth statutes, or whether those rights could be modified under section 52 (ii). The Australian High Court considered this question in a series of decisions extending over some thirty years.

In Bond v. The Commonwealth (1903), 1 C.L.R. 13 at 24, Grif-

62 (1900) $63 \& 64$ Vict. c. 12 (U.K.). 
fith C.J. expressed the view that the existing rights of a public servant under section 84 included a right to receive a salary at the existing rate until that rate was lawfully reduced by a competent authority. He noted the argument that the preservation of the officer's existing rights in section 84 precluded any such reduction, and held that it was unnecessary for him to decide the question in that case. When confronted with the issue in the subsequent case of Cousins v. The Commonwealth (1906), 3 C.L.R. 529 , the same judge once again avoided deciding it by the somewhat artificial expedient of construing a pre-Union statute setting the salaries of public servants as a purely temporary measure, not intended to restrict the power of the Commonwealth Parliament, and so effectively beyond the scope of section 84 of the Constitution. ${ }^{63}$

If these early decisions were inconclusive, by the 1920's judicial opinion had firmed. In three distinct cases, various High Court judges consistently expressed the view that section 84 protected the "existing and accruing rights" of public servants from any future diminution by statute. ${ }^{64} \mathrm{~A}$ passage from the joint opinion of Rich and Dixon JJ. in Pemberton v. The Commonwealth (1933), 49 C.L.R. 382 is representative:

The objects of the provision [section 84] were to provide for the transfer of officers, [and] to safeguard the interests of public servants transferred.... The future relations of the officers to the Commonwealth were necessarily to be governed by Commonwealth law. But, in order that this law might not diminish the rights of the officer, the constitutional provision was included preserving existing and accruing rights. Neither State nor Commonwealth could lessen the officer's pension or other rights.... Doubtless sec. 84 is a very special provision. Unlike the rest of the Constitution, it is directed to private rights. But it operates to control the exclusive power of the Parliament expressly given by sec. 52(ii) to legislate with respect to matters relating to transferred Departments. 65

Theae cases, then, are persuasive authority for the view that the word "existing" in section 35 of the Canadian Constitution

63 See especially the judge's statement of the main issue in the case at 536 and his reasoning at 538-540. For discussion of the case, see Le Leu v. The Commonwealth (1921), 29 C.L.R. 305 at 313, 314-316 (Aust. H.C.).

64 See Le Leu v. The Commonwealth (1921), 29 C.L.R. 305 (Aust. H.C.), per Higgins J. at 314-315; Lucy v. The Commonwealth (1923), 33 C.L.R. 229 (Aust. H.C.) per Knox C.J. at 238, per Isaaes J. at 243-244, per Higgins J. at 250, per Starke J. at 253-254; Pemberton v. The Commonwealth (1933), 49 C.L.R. 382 (Aust. H.C.), per Rich and Dixon JJ. at 388-389, per Starke J. at 391, per Evatt J. at 392, per McTiernan J. at 397.

65 At $388-389$. 
does not preserve the liability of the rights mentioned there to override by ordinary statute. Their authority is enhanced by the fact that the Australian Constitution virtually invites the argument that section 84 was intended solely to preserve the rights concerned from the effects of the constitutional changeover, and not to entrench them as against future legislation. ${ }^{66}$ With section 35 of our Constitution, no such argument is possible. The function of shielding native rights from any adverse effects of the new Charter is already performed by section 25 . If section 35 does not entrench aboriginal and treaty rights, it is hard to see what purpose it serves.

But what rights are entrenched? I will consider here several basic questions about the content of section 35, dealing first with treaty rights and then aboriginal rights.

c) Treaty rights

I will argue that the expression "existing... treaty rights" in section 35 refers to rights held under treaties existing on 17 April 1982, where those rights had not previously been extinguished. Two groups of treaty rights are therefore excluded: first, those arising under treaties concluded after 17 April 1982, and second, those terminated prior to that date. I will briefly consider each in turn.

It could be contended that "existing treaty rights" means rights flowing from any treaties that happen to exist from time to time, whether concluded before or after the Constitution was proclaimed. On this view a treaty made only in 1984 would be covered, as well as one made prior to 17 April 1982. This interpretation derives some support from the principle that the law should be regarded as always speaking, and as applying to new circumstances as they arise. ${ }^{67}$ It arguably follows that section 35 continuously operates so as to apply to new treaties when they come into existence.

66 By way of parallel, see sections 129 and 130 of the British North America Act, 1867, which preserve all officers "existing... at the Union" (s. 129), subject to future legislation.

67 See, e.g., section 10 of the Interpretation Act, R.S.C. 1970, c. I-23, which provides: "The law shall be considered as always speaking, and whenever a matter or thing is expressed in the present tense, it shall be applied to the circumstances as they arise, so that effect may be given to the enactment and every part thereof according to its true spirit, intent and meaning." This section does not, of course, govern the Constitution Act, 1982, which is technically a U.K. statute enacted for Canada. But it can be argued that section 10 merely embodies a standard rule of construction. 
Several factors speak against this contention. As noted previously, there is a significant contrast in phraseology between section 35 and section 25 . The term "existing" is absent from the latter provision, which, we have seen, explicitly extends to certain agreements to be made in future between the Crown and native peoples. The more restrictive wording of section 35 implies that future treaties are excluded. Another factor favours this construction. The section states that existing treaty rights are "hereby recognized." The phraseology suggests a definite act of recognition pinpointed in time, rather than a continuing recognition operating indefinitely into the future. Admittedly, this inference rests largely on the word "hereby," which is not found in the French version. ${ }^{68}$ So the argument is less than conclusive. On balance, however, the section seems to make best sense when read as referring to a definite body of treaties in existence on 17 April 1982. ${ }^{69}$

The position will change if the proposed new subsection $35(3)$ is passed. This provision states that, for greater certainty in subsection 35(1), "treaty rights" includes rights that now exist by way of land claims agreements "or may be so acquired." Thus, future agreements will qualify for protection. The wording of the amendment suggests, moreover, that the true meaning of "existing" in subsection $35(1)$ is "existing from time to time," because it provides in effect that the expression "existing ... treaty rights" includes "existing rights under existing or future land claims agreements." This does not make sense unless it means "such rights as exist from time to time under existing or future agreements."

It seems clear in principle that any treaty rights that were lawfully extinguished prior to 17 April 1982 are not covered by section 35 . To take the clearest case, treaty provisions imposing obligations on the Crown that were fully carried out, as by a onetime payment of money, would not confer existing rights within the meaning of the section. Similarly, treaties or particular treaty clauses that were lawfully terminated before the Constitution came into force do not benefit. We saw earlier that, prior to the enactment of section 35, a competent Canadian legislature could alter the terms of a treaty or repudiate it altogether. It may be doubted, however, whether many significant instances of

68 The French text simply states that the rights in question "sont reconnus et confirmés."

69 See the interesting discussion in The Yuri Maru, [1927] A.C. 906, where the Privy Council came to a similar conclusion in interpreting a statute using the word "existing." 
such action can be found. Legislation of a highly explicit variety would seem necessary to release the Crown from promises made in an agreement from which it gained a substantial benefit at the expense of the private signatories.

One must distinguish here between a statute that specifically nullifies a treaty right and an enactment that merely fails to implement or observe it. Legislation of the latter kind would not relieve the Crown of its obligations under the treaty. Where the wording does not indicate that the treaty was present to the mind of Parliament and consciously repudiated, then the promises made in the agreement would ordinarily remain intact, if unfulfilled. Thus, legislation imposing general restrictions on fishing would not release the Crown from specific treaty promises regarding native fishing rights, even though those undertakings are not observed by the statute. The treaty provisions have been infringed but not terminated. It follows that in order to determine what treaty rights are covered by section 35 one looks to the texts of treaties in force as of 17 April 1982, not to legislation. In a nutshell, section 35 recognizes and affirms existing treaty rights not existing statutory rights.

The interpretation advanced here is not entirely novel. A similar view has been accepted in practice as regards section 88 of the Indian Act. ${ }^{70}$ This provides that "subject to the terms of any treaty" provincial laws of general application apply to Indians. Presumably, if a treaty were explicitly terminated by federal legislation, it would no longer shield Indians from provincial statutes under section 88 . But the mere fact that a treaty has not been fully honoured by the federal Crown or Parliament has never been thought to disqualify it for the purposes of section 88 .

I suggest, then, that section 35 of the Constitution performs much the same function as regards Canadian legislation in general that section 88 of the Indian Act has long fulfilled respecting provincial statutes. Any enactments, past or future, that do not conform to the promises made by the Crown in its historical agreements with native Canadians are to that extent inapplicable to the peoples in question, so long as those promises were still binding on 17 April 1982.

d) Aboriginal rights

I will argue that the expression "existing aboriginal ... rights" covers at least two distinct types of rights regarding land: first,

70 R.S.C. 1970 , c. I-6. 
a right of exclusive use and occupancy of certain traditional lands, where native title thereto had not been lawfully extinguished prior to 17 April 1982 ; second, a right of compensation as regards native lands taken by the government without native consent before 17 April 1982, where this taking extinguished the native right of occupancy, but did so without payment of fair compensation, except where compensation was explicitly ruled out.

i) The right of occupancy

The doctrine of aboriginal title stems from the fact that native American peoples depended upon the land for their subsistence and prosperity. The common law, as it evolved in the American colonies during the 17th and 18th centuries, eventually recognized, after some initial uncertainty, that native groups held legal rights to lands in their possession. This position was officially confirmed by the British Crown in the Royal Proclamation of 7 October 1763, which applied both to the established English colonies in America and to the territories newly ceded to the Crown by France and Spain. ${ }^{71}$

Aboriginal title, at common law, was viewed as a communal right of exclusive use and occupancy constituting a burden on the underlying title of the Crown, which held the ultimate fee. The native right of possession had one major limitation: in principle, it could not be transferred to non-natives without official sanction, although in practice such transfers frequently occurred. ${ }^{22}$ These features were reflected in the Royal Proclamation of 1763 , which established a uniform legal regime governing Indian lands throughout British territories in North America, and also set up a temporary Indian territory in the American interior, closed for the time being to white settlement.

The Proclamation is a complex instrument, dealing with a variety of matters, both Indian and non-Indian. ${ }^{73}$ It announces the new boundaries and constitutions of Quebec and several other

71 For a review of the relevant legal materials, see: Slattery, Land Rights of Indigenous Canadian Peoples, supra, note 1 . For historical background to the Proclamation of 1763 , see Stagg, Anglo-Indian Relations in North America to 1763 and an Analysis of the Royal Proclamation of 7 October 1763 (Research Branch, Indian and Northern Affairs Canada, 1981).

72 For discussion of the common law doctrine, see Slattery, Ancestral Lands, Alien Laws, supra, note 1.

73 For detailed analysis of the scope and legal effects of the Proclamation, see Slattery, Land Rights of Indigenous Canadian Peoples, supra, note 1, 191-349. 
colonies established in the newly-ceded territories, and also provides for land grants to disbanded military personnel. More important, for our purposes, are the detailed provisions regarding Indian lands found in the final portion of the instrument.

This Part opens with a preamble stating that:

it is just and reasonable, and essential to Our Interest and the Security of Our Colonies, that the several Nations or Tribes of Indians, with whom We are connected, and who live under Our Protection, should not be molested or disturbed in the Possession of such Parts of Our Dominions and Territories as, not having been ceded to, or purchased by $\mathrm{U}_{\mathrm{s}}$, are reserved to them, or any of them, as their Hunting Grounds. . . .74

The text goes on to prohibit the Governors of any British colonies in America from issuing patents for any Indian lands that have not been ceded to the Crown, and orders the removal of settlements on such lands. It also provides that, in view of the "great Frauds and Abuses" committed in purchasing lands of the Indians, and to the end that "the Indians may be convinced of Our Justice, and determined Resolution to remove all reasonable Cause of Discontent," no private purchases of Indian lands shall take place in future. Such lands may be purchased only for the Crown in a public meeting with the Indians. These provisions were made applicable to all British colonies and territories in America, and so governed Quebec, old Nova Scotia (including present-day New Brunswick and Prince Edward Island), Newfoundland, Rupert's Land, the Thirteen Colonies, and the Floridas, as well as the unorganized territories to the west. ${ }^{75}$

The Proclamation also defined the boundaries of a special Indian territory located in the heart of the continent, which "for the present" would be closed to settlement and purchases. The boundaries were described as the limits of Rupert's Land and Quebec on the north and north-east, the Appalachian mountains on the east, and the limits of East and West Florida on the south. No western boundary was stipulated. It was envisaged that this area would eventually be opened up for settlement, in which case the land purchase procedure laid down by the Proclamation would come into effect.

74 The most accurate printed text of the Proclamation is that given in Brigham, ed., British Royal Proclamations Relating to America, 212-218.

75 For discussion of the Proclamation's territorial scope, see Slattery, Land Rights of Indigenous Canadian Peoples, supra, note 1, 204-282, 329-349; Narvey, "The Royal Proclamation of 7 October 1763. The Common Law, and Native Rights to Land within the Territory Granted to the Hudson's Bay Company" (1973-74), 38 Saskatchewan Law Review 123; Stagg, supra, note $71,350-391$. 
The precise geographical extent of the Indian Territory has attracted a certain amount of academic and judicial discussion.

$\therefore \quad$ The Supreme Court of Canada has held, for example, that the former Hudson's Bay Company Territory, Rupert's Land, was excluded from the Indian Territory. ${ }^{76}$ This holding is undoubtedly correct. But preoccupation with the Indian Territory should not blind us to the fact that it was a temporary creation, and by no means the most important and enduring feature of the Proclamation. Far more significant for contemporary purposes is the fact that the Proclamation recognized Indian land rights throughout British territories in North America, both within and without the Indian Territory, and provided for their extinguishment by voluntary surrender to the Crown. ${ }^{\pi}$

It is sometimes assumed that the Proclamation recognized native land rights only in the Indian Territory. But the text clearly rules out this interpretation..$^{78}$ Thus, after describing that Territory, the Proclamation goes on to require the removal of all persons who have settled on any lands within the Territory proper "or upon any other Lands, which, not having been ceded to, or purchased by Us, are still reserved to the said Indians as aforesaid" (emphasis added), the quoted phrase referring back to the general description in the preamble. This provision presupposes that unceded Indian lands located outside the Indian Territory are also reserved for Indian use. Again, the Proclamation provides that no private person shall make any purchases from the Indians "of any Lands reserved to the said Indians, within those Parts of Our Colonies where We have thought proper to allow Settlement," and that if the Indians are ever inclined to dispose of such lands, they shall be purchased for the Crown in a public assembly. Since the Indian Territory was, for the time being, expressly closed to "any Purchases or Settlements whatever," this provision could only apply to Indian lands found outside the

76 Sigeareak v. The Queen, [1966] S.C.R. 640 at 649-650. It is submitted that this decision is confined to an interpretation of the limits of the Indian Territory, and does not foreclose discussion of the territorial application of other sections of the Proclamation, such as the land purchase provisions, that were not in issue in that case or discussed in the judgment.

77 See St. Catherine's Milling and Lumber Co. v. The Queen (1888), 14 A.C. 46 at 54, where the Privy Council referred to "the general provisions made by the Royal Proclamation in favour of all Indian tribes then living under the sovereignty and protection of the British Crown."

78 For detailed consideration of this question, see Slattery, Land Rights of Indigenous Canadian Peoples, supra, note 1, 217-227; Narvey, supra, note 75 . 
Indian Territory in colonies where settlement was permitted. If the only lands reserved for Indians were those positioned inside the Territory, the provision could not be carried out.

The concept of aboriginal title at common law logically entailed that native peoples might in principle use and exploit their lands in any manner they saw fit. They were not tied to any particular mode of land use, much less to "traditional" uses. An Indian band that originally subsisted by hunting and fishing might turn to farming when game stocks became depleted, or to ranching, lumbering or mining. To hold that native groups were permanently wedded to certain historical uses would, in some cases, have been to sentence them to slow starvation, and in any case to deny native peoples the right to adapt their manner of life to meet new conditions, to exploit their lands in a more productive manner, and generally to enhance their material conditions.

The doctrine of aboriginal titles did not envisage that native peoples were ipso facto tied down to particular tracts of land, with fixed and permanent boundaries. Such demarcation might, of course, be achieved by treaty or statute. However, in the absence of such acts, it was accepted in practice that the boundaries of indigenous territories tended to fluctuate over time, in response to demographic, economic or security factors. A band or nation of Indians that moved from one location to another in search of better hunting conditions would not thereby forfeit any claim to aboriginal title. In effect, the doctrine arguably recognized that native peoples held rights to such lands as they actually occupied at any given period. Thus, when the Crown wished to negotiate the surrender of a particular tract of land, it normally dealt with the native people actually possessing and claiming the land. There was no inquiry whether the group had been there from time immemorial or from the period when the Crown first asserted sovereignty. Rather, the Crown attempted to ascertain which group had the closest on-going links with the land in question and dealt with those people. Any other approach would have been unworkable.

Thus, within certain limits, native people were free to move from one place to another. In gaining a new homeland they would, after some time, necessarily lose their rights to their former lands. Those lands would normally become available for repossession by another native group. One clear limit was posed to this fluid scheme of things. Where lands were lawfully surrendered to the Crown by a native group holding title to them, 
those lands would become Crown lands and would not be available for repossession by other native groups. By the same token, where the Crown by valid legislation extinguished aboriginal rights to a particular tract, the land would be withdrawn from the pool available for native possession. The same effect would be achieved where the Crown lawfully appropriated land not at that time subject to the rights of any native group.

This doctrine worked, on the whole, in a simple and convenient manner. Lands were, at any given time, divided into two broad categories: namely "aboriginal lands" and lands freed of the burden of native title. Where the Crown wished to secure a portion of aboriginal territory for its own purposes, it sought out the current native occupants and negotiated a surrender. So long as land had not been freed of aboriginal title by governmental act, it was available for appropriation and transfer as among native peoples themselves.

It follows, then, that where an aboriginal people possessed and claimed a certain tract of land as of 17 April 1982, and aboriginal title thereto had not been lawfully extinguished prior to that date, the people in question held an existing aboriginal right of occupancy within the scope of section 35 of the Constitution.

A more difficult case arises where an aboriginal people were at some point prior to 17 April 1982 factually dispossessed of their lands, but this dispossession did not in itself effect a lawful termination of their title. In principle, the aboriginal right of occupancy would continue to exist, and therefore qualify under section 35. However, the question is complicated by the possible effect of statutes of limitation and other factors, and cannot be considered here.

When aboriginal title is understood in this fashion, it becomes clear how the development of distinct communities of Métis in the Canadian West was accompanied by the emergence of distinct land rights. Aboriginal title was not, of course, confined to persons of pure native stock. It was a collective right vesting in an aboriginal group, membership in which was not necessarily restricted to full-blooded natives. Non-natives who were accepted as group-members by virtue of marriage or adoption would participate in the group's collective title. Children of mixed parentage who were born to group-members would presumptively inherit a share in the group's rights.

Just as an aboriginal band might sub-divide or produce offshoots, with the resulting sub-groups each gaining title to lands they actually occupied, so also communities composed primarily 
of mixed-bloods might coalesce and eventually emerge as distinct aboriginal groups holding rights to any lands possessed. ${ }^{79}$ If there was previously any doubt whether Métis might qualify as holders of aboriginal rights, subsection 35(2) of the Constitution dissipates it, providing that Métis are included among the peoples whose aboriginal rights are recognized in the Act. ${ }^{80}$

ii) The right to compensation

I suggest that where aboriginal land rights were compulsorily extinguished by governmental act prior to 17 April 1982, there arose a right of just compensation which vested in the native people concerned, unless such compensation was explicitly ruled out by the expropriating act. This right is an aboriginal right within the meaning of section 35 and is covered there unless nullified at some previous time.

The subject of compensation is a complex one. Here I can do no more than sketch out the main lines of argument and consider briefly several objections that might be brought.

The legal basis of the right to compensation is the presumption that the Crown will not deprive a subject of his lands without affording him recompense for the loss. This presumption is based on sound policy considerations. Property is normally taken by the Crown for the benefit of the community as a whole. It is only fair, in most cases, that the cost of the taking be borne by the community and not fall exclusively on the shoulders of the person affected.

The general rule was applied by the Supreme Court of Canada in Manitoba Fisheries Ltd. v. The Queen, [1978] 6 W.W.R. 496. Mr. Justice Ritchie, speaking for the court, adopted the words of Lord Atkinson in Attorney General v. De Keyser's Royal Hotel Ltd., [1920] A.C. 508 at 542 (H.L.):

The recognized rule for the construction of statutes is that, unless the words of the statute clearly so demand, a statute is not to be construed so as to take away the property of a subject without compensation. 81

The court also referred to the approach of Lord Radcliffe in Belfast Corp. v. O.D. Cars Ltd., [1960] A.C. 490 at 523 (H.L.), where he stated:

79 See MeNeil, Native Claims in Rupert's Land and the North-Western Territory: Canada's Constitutional Obligations, supra, note 26, 14-18.

80 Subsection 35(2) provides: "In this Act, 'aboriginal peoples of Canada" includes the Indian, Inuit and Métis peoples of Canada."

81 Quoted at 503. For Justice Ritchie's application of this rule, see the judgment at 511. 
On the one hand, there would be the general principle, accepted by the legislature and scrupulously defended by the courts, that the title to property or the enjoyment of its possession was not to be compulsorily acquired from a subject unless full compensation was afforded in its place.... Aspects of this principle are found in the rules of statutory interpretation devised by the courts, which required the presence of the most explicit words before an acquisition could be held to be sanctioned by an Act of Parliament without full compensation being provided, or imported an intention to give compensation and machinery for assessing it into any Act of Parliament that did not positively exclude it. (emphasis added) 82

It would seem that aboriginal peoples stand to benefit from the principle as much as other subjects of the Crown. And in fact the right of native Canadians to compensation for lands taken up for settlement has been officially acknowledged on a number of occasions. To take but one example, the North-Western Territory was transferred to Canada in 1870 on the following condition:

the claims of the Indian tribes to compensation for lands required for purposes of settlement will be considered and settled in conformity with the equitable principies which have uniformly governed the British Crown in its dealings with the aborigines. 83

Interestingly, the clause adopts as a standard certain "equitable principles" that are said to have uniformly governed the Crown. Thus, the natives of the North-Western Territory were not meant to be placed in any specially privileged position, but were merely to enjoy the same right of compensation held by aboriginal peoples in British North America generally. ${ }^{84}$

To the extent that section 35 recognizes certain subsisting rights to compensation by aboriginal peoples, it would also seem to place a charge on the consolidated revenue fund of the government concerned. By way of parallel, the High Court of Australia held in Bond v. The Commonwealth (1903), 1 C.L.R. 13 at 22 that a constitutional provision preserving the existing and accruing rights of certain public servants operated as a charge on the Commonwealth Revenue of a sufficient sum to give effect to it, and as ample authority to the Executive to make the necessary payments.

82 Quoted at 503-504.

83 Quoted in McNeil, Native Claims in Rupert's Land and the NorthWestern Territory: Canada's Constitutional Obligations, supra, note 26, 13.

- $\quad 84$ See discussion in McNeil, ibid., 13-21. 
Two principal objections might be made to the general argument outlined above. First, aboriginal land rights were not of such a nature as to benefit from the common law presumption favouring compensation. Second, even if a right to compensation arose upon a governmental taking of aboriginal lands, that right is not an aboriginal right within the meaning of section 35 .

The first contention draws upon the decision of the United States Supreme Court in Tee-Hit-Ton Indians v. United States (1954), 348 U.S. 272. The question there was whether a group of Indians residing in Alaska were entitled to compensation under the Fifth Amendment to the Constitution for a taking by the United States of timber from aboriginal lands claimed by the group. The Fifth Amendment provides, in part, that "no person shall... be deprived of life, liberty, or property, without due process of law; nor shall private property be taken for public use without just compensation." The court held that, where Congress had by treaty or other act declared that Indians would thereafter hold their lands permanently, compensation had to be paid for a subsequent taking. The recognition might be made in a variety of ways; no particular form was necessary. But there had to be a definite intention to accord legal rights, not merely permissive occupation. ${ }^{85}$ Where governmental recognition had not been given, Indian occupation of land under aboriginal title did not create rights protected by the Fifth Amendment or any other principles of law against a taking by the United States. ${ }^{86}$ The aboriginal interest in land was not a property right but a right of occupancy terminable by the sovereign without any legally enforceable obligation to compensate the Indians. ${ }^{87}$ The court stated:

Every American schoolboy knows that the savage tribes of this continent were deprived of their ancestral ranges by force and that, even when the Indians ceded millions of acres by treaty in return for blankets, food and trinkets, it was not a sale but the conqueror's will that deprived them of their land. 88

The relevancy of the Tee-Hit-Ton decision to Canada is disputed. In the Calder case, three justices of the Supreme Court appeared to accept the rules laid down there as applicable to British Columbia, while three others considered that the taking of aboriginal lands in Canada gave rise to a right of just com- 
pensation. ${ }^{89} \mathrm{I}$ submit that the latter view is correct. The TeeHit-Ton decision rests upon a contentious interpretation of the particular policies pursued by the United States government regarding the Indians in the years following the American Revolution. It does not reflect the legal position obtaining in British colonial territories. That position, as embodied in the Royal Proclamation of 1763 , was that unceded lands in native possession were recognized as reserved to their aboriginal occupants until surrendered to the Crown on agreed terms. It was not contemplated that native peoples might properly be deprived of their lands without payment of compensation. As British subjects, native Canadians were entitled to the protection of the Crown to the same extent as non-native Canadians. The schoolboy vision of American history invoked by the American Supreme Court was never the Canadian legal reality.

Nevertheless, it could be argued that, even assuming aboriginal peoples enjoy a right of compensation for lands taken, this right is not an aboriginal right within the meaning of section 35. The right of compensation arises only upon the extinguishment of an aboriginal right to land. As such it is a right held in lieu of an aboriginal right, but not an aboriginal right itself.

This argument depends upon what seems an artificially narrow construction of section 35 . The right of compensation for a taking of aboriginal lands springs directly from the common law recognition of aboriginal title as a legally compensable interest. The fact that native Canadians were the first occupants of this land is the basis for both the aboriginal right of possession and the aboriginal right to compensation for a deprivation of possession. If one right falls within the scope of section 35 , it would seem the other must as well. The wind that bends the tree-trunk bends the branches.

The Constitution addresses a number of major grievances long held by native Canadian peoples. It does so in language of the most general variety, leaving much to judicial initiative. In effect, I suggest, the Constitution mandates the courts to develop a set of workable principles leading to the equitable settlement of outstanding native claims and the future protection of their rights. The field is now open to the judiciary. Is it too much to hope for a fair catch and a clean run, and not a fumble?

89 Supra, note 23 per Judson J. at 166-168, per Hall J: at 173, 196-197, 219. 